\title{
Remote sensing techniques to assess chlorophyll fluorescence in support of crop monitoring in Poland
}

\begin{abstract}
The increase in demand for food and the need to predict the impact of a warming climate on vegetation makes it critical that the best tools for assessing crop production are found. Chlorophyll fluorescence (ChIF) has been proposed as a direct indicator of photosynthesis and plant condition. The aim of this paper is to study the feasibility of estimating ChIF from spectral vegetation indices derived from Sentinel-2, in order to monitor crop stress and investigate ChIF changes in response to surface temperatures and meteorological observations. The regressions between thirty three Sentinel-2-derived VIs, and ChIF measured on the ground were evaluated in order to estimate the best predictors of ChIF. The r-Pearson correlation and polynomial linear regression were used. For maize, the highest correlation between ChIF and VIs were found for NDII ( $r=0.65)$ and for SIPI $(r=-0.68)$. The weakest relationship between VIs and ChIF were found for sugar beets. Despite this, it should be noted that the highest correlation for sugar beets appeared for $E V I(r=0.45)$ and S2REP $(r=0.43)$. The results of this study indicate the need for a synergy of low and high resolution satellite data that will enable a more detailed analysis for estimating fluorescence and its relation to climatic conditions, environmental aspects, and VIs derived from satellite images.
\end{abstract}

Keywords

Spectral vegetation indices $\cdot$ land surface temperature $\cdot$ JECAM $\cdot$ Sentinel satellites

(C) University of Warsaw - Faculty of Geography and Regional Studies

\section{Introduction}

The remote sensing of chlorophyll fluorescence is a rapidly advancing front in terrestrial vegetation science, with emerging capabilities in space-based methodologies and prospects for diverse applications (Mohammed et al. 2019). Chlorophyll fluorescence (ChIF) differs from the traditional reflectance-based vegetation indices as it refers to the red and far-red wavelengths (650-800 nm) emitted by chlorophyll a pigments, which are measured a few nanoseconds after light absorption (Damm et al. 2015). Accompanied by a photochemical reaction and heat dissipation, chlorophyll fluorescence emission is one of three pathways used for light consumption in the photosystem (Genty et al. 1989). Chlorophyll fluorescence is light that is re-emitted at a longer wavelength after being absorbed by chlorophyll molecules. Variable chlorophyll fluorescence is only observed in chlorophyll $a$, in photosystem II. Plant physiology can be investigated by measuring the intensity and nature of the variable chlorophyll fluorescence, and by using the protocols that have been developed (Pilar 2013). In many ChIF parameters, Fv/Fm is the maximum quantum yield (Photochemical efficiency of PSII) and this is used to characterize the conversion efficiency of the light energy of the PS II reaction center; its numerical changes are of special significance. However, conventional methods of assessing $\mathrm{Fv} / \mathrm{Fm}$ from field observations that involve site-specific, complicated parameterizations and calculations, make it difficult to apply over large agricultural areas (Damm et al. 2015). These

\author{
Radosław Gurdak $\mathbb{C}^{1}$ \\ Maciej Bartold $\mathbb{C}^{2}$ \\ 'Department of Geoinformatics, Cartography and \\ Remote Sensing, Faculty of Geography and Regional \\ Studies, University of Warsaw, Warsaw, Poland \\ e-mail: radoslaw.gurdak@igik.edu.pl \\ ${ }^{2}$ Remote Sensing Centre, Institute of Geodesy and \\ Cartography, Warsaw, Poland \\ e-mail: maciej.bartold@igik.edu.pl \\ Received: 28 April 2020 \\ Accepted: 13 August 2020
}

shortcomings can be overcome through the complementary use of satellite imagery.

Chlorophyll fluorescence is widely used to monitor crop stress, while multi-frequent satellite observations allow for the retrieval of parameters such as pigment concentration and photosynthetic active radiation (PAR), which can be used for ChIF estimations. It is known that crop yield can be reduced by stress factors such as extreme temperatures, direct sunlight, and a shortage of water and nutrients (Baligar et al. 2001; DabrowskaZielińska et al. 2011), which affect or block plants' metabolism, growth, and development (Kranner et al. 2010). Compared to reflectance, induced fluorescence is considered to be a more accurate indicator of plant state and to be able to detect stress impacts at earlier growth stages (McFarlane et al. 1980; Kancheva 2008).

Vegetation indices derived from satellite images have, alternatively, been used to estimate plant stress over larger areas based on spectral reflectance (Bochenek et al. 2017; Gurdak \& Grzybowski 2018). Unfortunately, most of the common vegetation indices measure only the "greenness" of the land cover and not photosynthesis itself. Consequently they have little or no sensitivity to short-term physiological changes in leaves (ZarcoTejada et al. 2013). In the short term (hours or days), green leaves remain green but reduce photosynthesis when they are stressed. At longer time scales, when prolonged stress causes premature 
senescence, the stress can be monitored as a change in, for example, NDVI (Mathobo et al. 2017). ChIF is directly related to crop photosynthesis and is, therefore, recognized as a more reliable indicator of stress than VIs (Meroni etal. 2009; Li etal. 2018). Therefore, some efforts have been undertaken in research centers in the past years to prepare effective methods for deriving this variable from satellite data and applying it to crop estimations for wheat, barley, and maize in Europe and Asia (Lopez-Lozano et al. 2015; Wei et al. 2019).

On the other hand, among Essential Climatic Variables (ECV), remote-sensing based on the land surface temperature (LST) can be used to estimate plant water-vapor loss ( $g_{1}$, water vapor) (Miguel Costa et al. 2013). This is potentially an indicator of stomatal opening, which in turn is strongly correlated with photosynthesis (Chaves et al. 2003; Jones 1992). In monitoring individual Essential Climatic Variables, such as air temperature, precipitation derived from meteorological stations is also required for studying photosynthesis dynamics (Gobron et al. 2006).

Photosynthesis is one of the most important photochemical processes, however, it is difficult to measure at field scale. One promising approach is the use of ChIF, which is directly related to photosynthesis and can be measured at field scale with remote sensing techniques (Drusch et al. 2017). In 2019, the European Space Agency (ESA) announced that it has signed a contract with Thales Alenia Space to lead the Fluorescence Explorer (FLEX) satellite mission, which is scheduled for launch in 2023. Also, taking advantage of Sentinel-3's (launched in 2018) optical and thermal sensors will lead to an integrated package of measurements that can assess plant health. With the Sentinel-2 satellites, also in orbit, there is the unique opportunity for using the data of all three missions synergistically for vegetation studies. The FLEX mission, in tandem with Sentinel 3, aims to provide global maps of vegetation fluorescence that can reflect photosynthetic activity, and plant health and stress. In turn, this is important for better agricultural management and food security.

Maize (Zea mays L.) is one of the most important grain crop in the world and is produced throughout the world under diverse environments. In developed countries, maize is consumed mainly as second-cycle produce, in the form of meat, eggs, and dairy products (Plessis 2003). In developing countries, maize is consumed directly and serves as a staple diet for some 900 million poor people. By 2025, maize will be the developing world's largest crop and between now and 2050 the demand for maize in the developing world is expected to double. Sugar beet (Beta vulgaris L. subsp. Vulgaris), on the other hand, is a root crop that is the world's second sugar source (after sugar cane): $24 \%$ of world production. During the years 2010-2019, Poland was in the top ten countries of sugar beet producers.

The most important requirement for growing maize and sugar beets is the soil, which must contain a large supply of plant food, be rich in humus, and have the property of retaining a great deal of moisture. Climatic conditions, both air and surface temperature, sunshine, rainfall, and wind, all have an important bearing upon high yields of maize and sugar beets (Rolph 1873; Fernandez-Armesto 2011). Drought and moisture stress that occurs during the different development stages of maize and sugar beets may reduce the final grain yield to different degrees, with the extent of yield reduction depending not only on the severity of the stress, but also on the stage of the plants' development (Wilson 1968; Claasen \& Shaw 1970). Due to the plants' water requirements, the most crucial phenological stages are at the stem elongation stage (maize) and at the rosette growth stage (sugar beets) (Doorenbos \& Kassam 1979; Garrod 1974).

The objective of this paper is to examine the feasibility of estimating ChIF from VIs derived from the Sentinel-2 satellite. Monitoring crop stress and investigating the climatic variables that affect the phenological dynamics associated with temporal changes in VIs are very important. We evaluated of the usefulness of thirty three Vls that monitored the impact of various environmental conditions by finding how they related to the ground measurements of ChIF. To monitor the stress conditions of plants, a detailed temporal analysis of meteorological parameters was carried out in combination with the temporal variability of VIs derived from Sentinel-2 images. In order to investigate the thermal stress we also observed the land surface temperature derived from Sentinel-3 at $1 \mathrm{~km}$ resolution, in conjunction with a meteorological database containing air temperature and precipitation. The outcome of the statistical analysis allowed the authors to find the relations between the chosen remote sensingbased indices and the ground measured ChIF. The authors were able to draw conclusions about the stress conditions that could impact the growth of maize and sugar beets, reflecting the changes in VI values, using temporal profiles for climate variables and land surface temperature.

\section{Study area}

The cropland test site is located in western Poland (Fig. 1), within the administrative area of Wielkopolska voivodeship (NUTS-2 PL41). Wielkopolska lies within the Odra river basin, however, $88 \%$ of the province's surface water drains into the Warta river basin. The flat terrain reaches elevation ranges of 60 to 90 meters. The western part of Wielkopolska is influenced by oceanic air masses that affect the mildness of the climate. On the other hand the eastern region of Wielkopolska is under the influence of a more distinctly continental climate. The average temperature for the year is approximately $8^{\circ} \mathrm{C}$. The growing season is one of the longest in Poland: the southern plains are characterized by a growing season of around 228 days, while the northern region gradually declines to 216 days. Precipitation ranges from 500 to $550 \mathrm{~mm}$ per year (Gurdak \& Grzybowski 2018).

The field site covered an area of $25 \mathrm{~km} \times 25 \mathrm{~km}$ and was located in Wielkopolska. The coordinates are as follows: upper left $16^{\circ} 38^{\prime} 21^{\prime \prime} \mathrm{E}, 52^{\circ} 10^{\prime} 31,500^{\prime \prime} \mathrm{N}$; lower right $17^{\circ} 0^{\prime} 53$ : E, $51^{\circ} 57^{\prime} 27^{\prime \prime} \mathrm{N}$. The site has been incorporated into JECAM (Joint Experiment of Crop Assessment and Monitoring), which is an international program for agricultural monitoring. JECAM was formed as part of the GEOGLAM (Group on Earth Observations Global Agricultural Monitoring) initiative and aims to carry out experiments to facilitate the fusion of satellite and field data for monitoring crop growth conditions and developing yield forecasting models. Its field experiments are carried out at a series of sites that represent the world's main cropping systems and rely on collecting in-situ vegetation biophysical parameters and meteorological measurements. In Poland, the JECAM site is characterized by a mixture of agricultural crops, with winter wheat, rape, maize, and sugar beets as the dominant species. The field pattern is composed of large fields that dominate the test site, intermixed with small fields. The crop calendar for winter cereals begins in September and lasts till July, while the spring/ summer crop calendar starts in April and ends in October. The main crop types are winter/spring wheat, triticale, and barley; and winter rape and rye, maize, sugar beets, alfalfa, and potatoes. The analyzes were performed for maize and sugar beets.

In 2018, seven fields of maize and five fields of sugar beets were selected. In 2019, the number of plots increased to twelve for maize and nine for sugar beets. The area of the fields was between 5 ha and 50 ha, and formed a rough square shape. The maize was seeded at the beginning of May and harvested at the turn of September and October. The date for seeding sugar beets was the beginning of April, the harvest was in mid-October. Figure 1 presents the distribution of corn and sugar beet fields on which the ground measurements were conducted. 


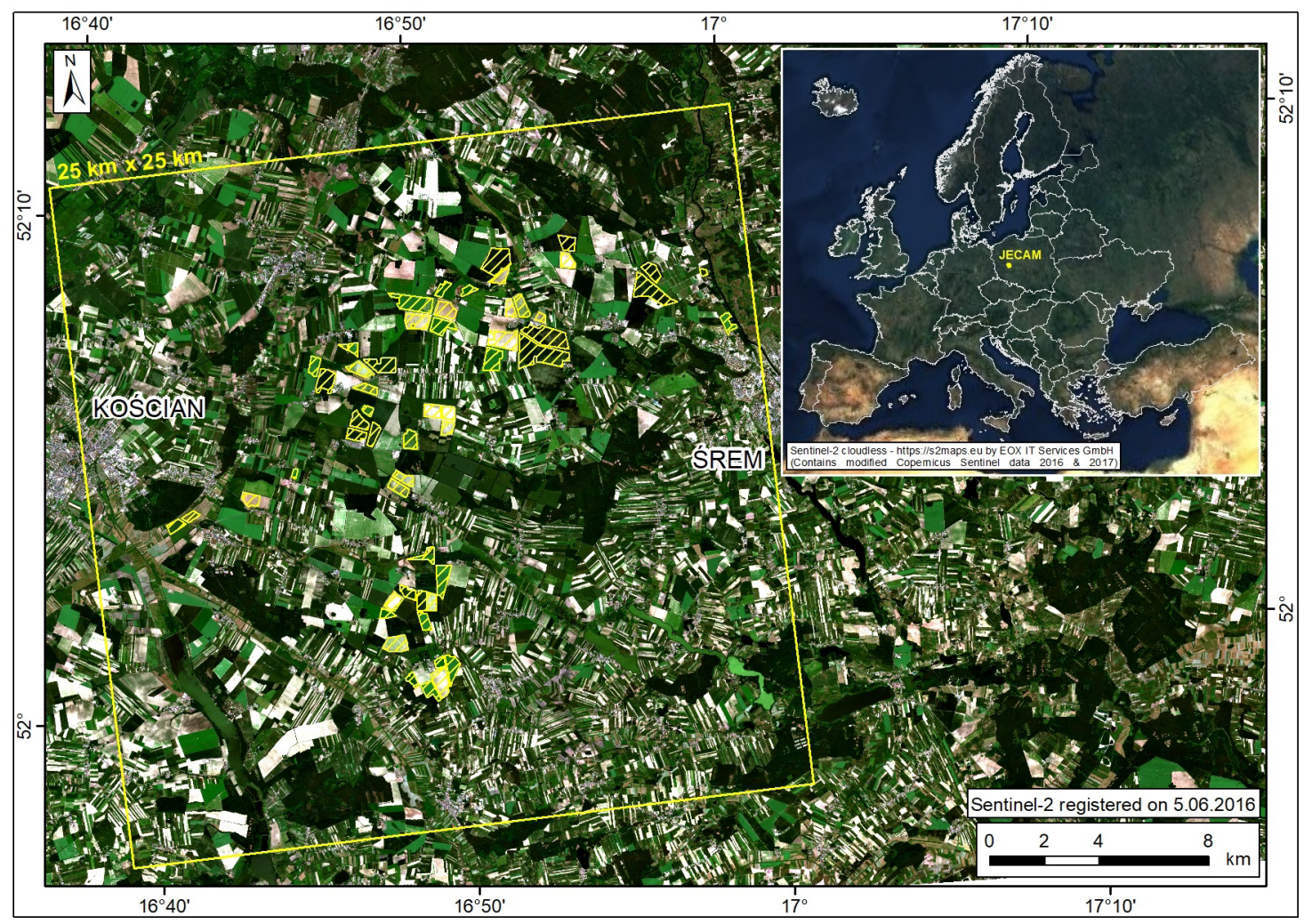

Figure 1. JECAM cropland site $25 \mathrm{~km} \times 25 \mathrm{~km}$, highlighted in yellow, with field sites where chlorophyll fluorescence were measured Source: own elaboration

\section{Materials and methods}

The ChIF ground measurements were conducted on the selected JECAM plots during the growing season. The actual locations of the plots of maize and sugar beet were investigated during field campaigns during July-August (2018-2019), taking into account the crop rotation system used in Poland. In-situ data were collected during two field campaigns: 7-9 August 2018 and 14-16 July 2019, at the stem elongation stage (maize) and at the rosette growth stage (sugar beets). These are the phases most susceptible to damage caused by drought and water stress (Doorenbos \& Kassam 1979; Garrod 1974).

During 2018-2019, nineteen and fourteen crop fields were registered as maize and sugar beets, respectively, in the study area (Fig. 2). Ground measurement data and the related satellitebased indices were grouped into two sets: a training set for determining relations (23 points), comprising $70 \%$ of all collected data, and a test set for verifying the established relations (10 points), comprising $30 \%$ of all data. The regression equations obtained as a result of the correlation analysis were next applied to generate ChIF values at the test points. Finally, these values were compared with the ground ChIF measurements and the differences between these two datasets were computed and statistically assessed.

We used an OS5p+ Pulse Modulated Chlorophyll Fluorometer (OPTI-SCIENCES, USA), which registers maximum quantum yield $\left(F_{V} / F_{M}\right)$ using the dark adapted test (Fig. 3). The dark adapted test is a measurement ratio that represents the maximum potential quantum efficiency of the Photosystem II if all capable reaction centers are open. This ratio is an estimate of the maximum portion of absorbed quanta used in the PSII reaction centers (Kitajima \& Butler 1975). By dark adapting, one is allowing the re-oxidation of the PSII and the relaxation of the NPQ. The appropriate dark adaption time was between 20 and 35 minutes for best results. A series of ten dark adapted white clips were provided with the system to be used for dark adaption measurement. The Elementary Sampling Unit (ESU) for ten clips was a $30 \times 30 \mathrm{~m}$ square, for the correct characterization of a 10 $\mathrm{m}$ Sentinel-2 pixel. The clips were placed on the leaves, with the black slider covering the cylindrical opening. After dark adaption, the end of the fiber optic bundle was placed in the cylindrical opening and the dark slide of the clip was opened allowing the sample to be exposed to the fiber optic bundle. $F_{v} / F_{M}$ value ranges of 0.66 to 0.83 were obtained from ground measurement. The approximate optimal value range is 0.79 to 0.83 for most land plant species, with lowered values indicating plant stress (Maxwell \& Johnson 2000). From the ten measurements carried out for each field, the average value was calculated as $F_{V} / F_{M}$.

Individual ranges for the electromagnetic spectrum are used for a detailed analysis of the state of plants. This is done by calculating the remote sensing vegetation indicators (VI); these are VIs that use various types of mathematical combinations of the respective spectral reflection indicators. VIs based on narrow ranges of the electromagnetic spectrum allow the content of individual substances in plants to be analyzed (Kycko 2017; Zagajewski et al. 2017).

The vegetation indices were selected and calculated from the Sentinel-2 Multispectral instrument. Cloudless satellite images were acquired on the nearest date to the ground measurement campaigns in order to ensure the comparability of the results (Sentinel-2B 2018/08/09 and Sentinel-2A 2019/07/25). The product type was Level-2A (after atmospheric correction). At the preliminary stage of the work thirty three vegetation indices, 


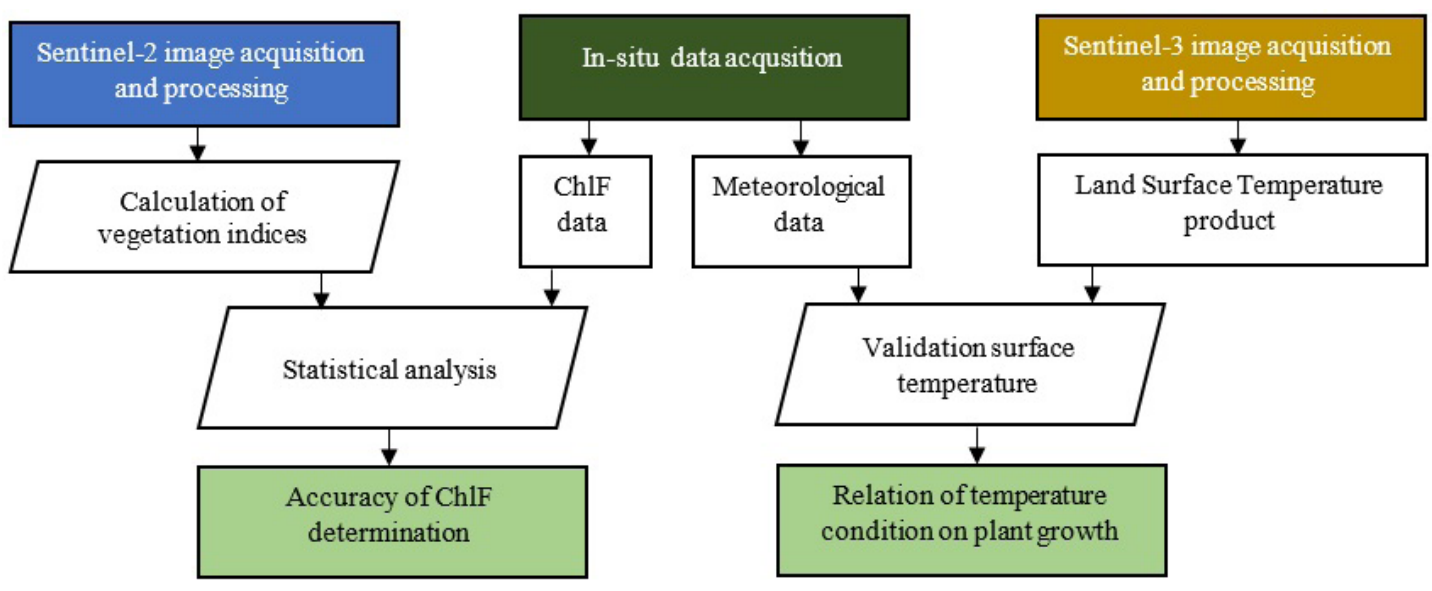

Figure 2. Scheme of work

Source: own elaboration

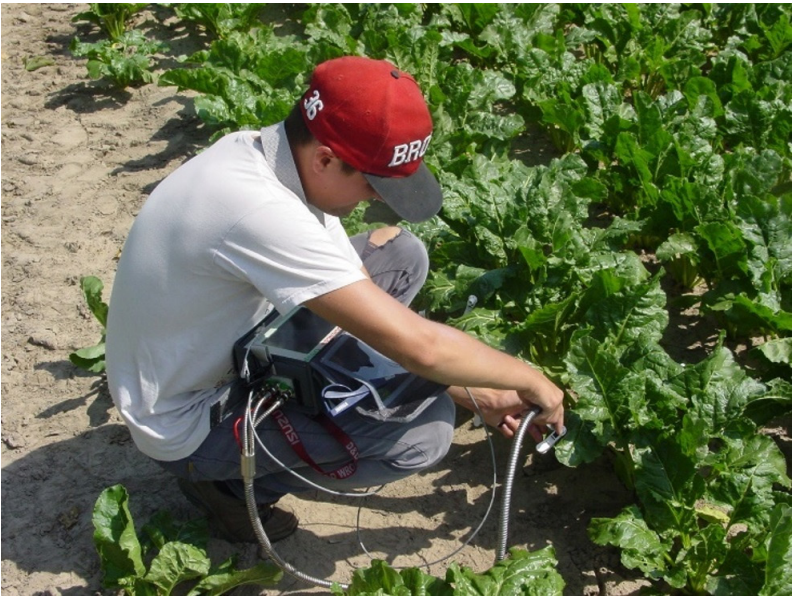

Figure 3. Chlorophyll fluorescence measurements on sugar beets with OS5p+ Pulse Modulated Chlorophyll Fluorometer Source: photo by Maciej Bartold

which characterized different aspects of crop condition and development, were derived from the Sentinel-2 data. These can be arranged into four groups (Table 1).

In order to analyze the thermal stress on plant growth we used the satellite temperature provided by the Copernicus Sentinel-3 mission. The temperature observations registered by a Sea and Land Surface Temperature Radiometer (SLSTR) instrument, mounted on-board both the Sentinel-3A and Sentinel3B satellites, was downloaded. The Level-2 LST product from the satellite-based temperature data that provides land surface parameters, generated a $1 \mathrm{~km}$ wide measurement grid, which was used in the analyzes.

The temperature readings from the measurement points were made on the basis of the Sentinel-3 LST data. Next we carried out a series of descriptive statistical calculations, which were presented on box plots (mean (red cross), median (black line in green box), maximum and minimum (upper and lower whisker), outliers (black dots), 1st quartile and 3rd quartile (sides of green box)) on surface temperature data (Fig. 5) on fields with sugar beets and maize within the JECAM area. The $1 \mathrm{~km}$ gridded Sentinel-3 images showing temperature were primarily resampled as ten meter resolution images in order to compare the results with the Sentinel-2 based vegetation indices and find the relation between temperature conditions and plant growth.

At the beginning of the Sentinel- 3 mission's operational term, (i.e. July 2017), maize and sugar beet croplands were taken into account for validating surface temperatures registered by satellites. We analyzed twenty-five cloud-free Sentinel-3 satellite images of the study area during 2018-2019 (Table 2).

In the next stage, meteorological data were compiled from weather stations adjoining the study area. Meteorological data were collected from the closest station, which belonged to the national meteorological data network (the town of Kornik, $\left.52^{\circ} 14^{\prime} \mathrm{N}, 17^{\circ} 6^{\prime} \mathrm{E}\right)$. Three meteorological parameters were analyzed in order to find anomalous weather periods that could affect the condition of the crops within study area: daily maximum and mean temperatures (measured at a height of $2 \mathrm{~m}$ from the ground) as well as the sum of the daily precipitation collected at the station from 2018 to 2019.

The statistical analyzes were conducted using Statistica 13 software. The acquired data had a normal distribution. The r-Pearson correlation analysis was used to calculate the correlation between the VIs and ChIF. Thereafter, linear polynomial regression was used to compute the ChIF from the VIs. In order to assess the accuracy, the following statistical analyses were used: $r$ coefficient, mean absolute error (MAE), root mean squared error (RMSE), and $p$-value. Verification was carried out on the test set (10 points), comprising $30 \%$ of all data.

\section{Results and discussion}

First, an analysis of the temporal variation of Vls was performed. Figure 4 illustrates the growth of maize and sugar beets during 2018-2019, and the differences in the plants' conditions observed within the two-year period. A time series of vegetation indices began in mid-May with the germination phase and ended with the heading of the maize and the development of the beets' root phases in July or August. Profiles were prepared for the commonly used indices that represented each of three chosen groups of VIs presented in Table 1. The average index values from the fields were calculated from the Sentinel-2 images and divided into the individual stages of crop development (Fig. 4).

The values of the NDVI and NDII indices increased during the germination and leaf development phases. During stem elongation and rosette growth the given indice values reached their peaks, after which the values decreased, achieving a level close to, or the same as, that at the beginning of growing season. The observed NDVI and NDII temporal curves are comparable to 
MISCELLANEA GEOGRAPHICA - REGIONAL STUDIES ON DEVELOPMENT

Vol. $25 \cdot$ No. $4 \cdot 2021 \cdot$ pp. 226-237 • ISSN: 2084-6118 • DOI: 10.2478/mgrsd-2020-0029

Table 1. Vegetation indices calculated from Sentinel-2 satellite imagery

\begin{tabular}{|c|c|c|c|c|}
\hline 1 & 2 & 3 & 4 & 5 \\
\hline Application & Index & Description & Equation & Reference \\
\hline \multirow{18}{*}{$\begin{array}{l}\text { Assessment of the } \\
\text { general condition of } \\
\text { vegetation }\end{array}$} & CTVI & $\begin{array}{l}\text { Corrected Transformed } \\
\text { Vegetation Index }\end{array}$ & $\mathrm{CTVI}=\frac{(\mathrm{NDVI}+0.5)}{|\mathrm{NDVI}+0.5|} * \sqrt{\mathrm{NDVI}+0.5}$ & Perry, 1984 \\
\hline & DVI & $\begin{array}{l}\text { Difference Vegetation } \\
\text { Index }\end{array}$ & $\mathrm{DVI}=a \mathrm{R}_{\mathrm{NIR}}-\mathrm{R}_{\mathrm{red}}$ & $\begin{array}{l}\text { Richardson, } \\
1977\end{array}$ \\
\hline & EVI & Enhanced Vegetation Index & $\mathrm{EVI}=\frac{R_{\text {NIR }}-R_{\text {red }}}{R_{\text {NIR }}+C_{1} * R_{\text {red }}-C_{2} * R_{\text {blue }}+L}$ & Huete, 1999 \\
\hline & GEMI & $\begin{array}{l}\text { Global Environmental } \\
\text { Monitoring Index }\end{array}$ & $\mathrm{GEMI}=\mathrm{n}(1-0.25 \mathrm{n})-\frac{R_{\text {red }}-0.125}{1-R_{\text {red }}}$ & Pinty, 1992 \\
\hline & GNDVI & $\begin{array}{l}\text { Green Normalized } \\
\text { Difference Vegetation } \\
\text { Index }\end{array}$ & $\mathrm{GNDVI}=\frac{R_{N I R}-R_{\text {green }}}{R_{N I R}+R_{\text {green }}}$ & $\begin{array}{l}\text { Gitelson, } \\
1998\end{array}$ \\
\hline & IRECI & $\begin{array}{l}\text { Inverted Red Edge } \\
\text { Chlorophyll Index }\end{array}$ & IRECI $=\frac{\left(R_{N I R}-R_{\text {red }}\right)}{R_{\text {rededge } 1} / R_{\text {rededge } 2}}$ & $\begin{array}{l}\text { Frampton et } \\
\text { al., } 2013\end{array}$ \\
\hline & MSAVI & $\begin{array}{l}\text { Modified Soil Adjusted } \\
\text { Vegetation Index }\end{array}$ & $\mathrm{MSAVI}=\frac{R_{N I R}-R_{\text {red }}}{R_{N I R}+R_{\text {red }}+L} *(1+L)$ & Qi et al., 1994 \\
\hline & MSAVI2 & $\begin{array}{l}\text { Modified Soil Adjusted } \\
\text { Vegetation Index } 2\end{array}$ & $\begin{array}{c}\text { MSAVI2 }=\frac{1}{2}\left[2 * R_{800}+1-\right. \\
\left.\sqrt{\left(2 * R_{800}+1\right)-8 *\left(R_{800}-R_{670}\right.}\right]\end{array}$ & Qi et al., 1994 \\
\hline & NDREI1 & $\begin{array}{l}\text { Normalized Difference Red } \\
\text { Edge Index } 1\end{array}$ & $\mathrm{NDREI} 1=\frac{R_{790}-R_{720}}{R_{790}+R_{720}}$ & $\begin{array}{l}\text { Gitelson And } \\
\text { Merzlyak, } \\
1994\end{array}$ \\
\hline & NDREI2 & $\begin{array}{l}\text { Normalized Difference Red } \\
\text { Edge Index } 2\end{array}$ & $\mathrm{NDREI} 2=\frac{R_{750}-R_{705}}{R_{750}+R_{705} * R_{445}}$ & Barnes, 2000 \\
\hline & NDVI & $\begin{array}{l}\text { Normalized Difference } \\
\text { Vegetation Index }\end{array}$ & $\mathrm{NDVI}=\frac{R_{N I R}-R_{\text {red }}}{R_{N I R}+R_{\text {red }}}$ & Rouse, 1974 \\
\hline & NRVI & $\begin{array}{l}\text { Normalized Ratio } \\
\text { Vegetation Index }\end{array}$ & $\mathrm{NRVI}=\frac{\frac{R_{\text {red }}}{R_{\text {NIR }}}-1}{\frac{R_{\text {red }}}{R_{\text {NIR }}}+1}$ & Baret, 1991 \\
\hline & REIP & Red Edge Inflection Point & $\operatorname{REIP}=700+40\left(\frac{\left(\frac{R_{670}+R_{780}}{2}\right)-R_{700}}{R_{740}-R_{700}}\right)$ & $\begin{array}{c}\text { Guyot And } \\
\text { Barnet, } 1988\end{array}$ \\
\hline & RVI & Ratio Vegetation Index & $\mathrm{RVI}=\frac{R_{\text {red }}}{R_{\text {NIR }}}$ & $\begin{array}{l}\text { Bannari et al., } \\
1995\end{array}$ \\
\hline & SATVI & $\begin{array}{l}\text { Soil Adjusted Total } \\
\text { Vegetation Index }\end{array}$ & $\mathrm{SATVI}=\frac{R_{N I R}-R_{\text {red }}}{R_{N I R}+R_{\text {red }}+L} *(1+L)-\frac{R_{S W I R}}{2}$ & Marsett, 2006 \\
\hline & SAVI & $\begin{array}{l}\text { Soil Adjusted Vegetation } \\
\text { Index }\end{array}$ & $\mathrm{SAVI}=\frac{(1+L)\left(R_{N I R}-R_{r e d}\right)}{R_{N I R}+R_{\text {red }}+L}$ & Huete, 1988 \\
\hline & SLAVI & $\begin{array}{l}\text { Specific Leaf Area } \\
\text { Vegetation Index }\end{array}$ & SLAVI $=\frac{R_{\text {NIR }}}{R_{\text {red }}+R_{\text {SWIR }}}$ & $\begin{array}{l}\text { Lymburger et } \\
\text { al., } 2000\end{array}$ \\
\hline & SR & $\begin{array}{l}\text { Simple Ratio Vegetation } \\
\text { Index }\end{array}$ & $\mathrm{SR}=\frac{R_{N I R}}{R_{\text {red }}}$ & Birth, 1968 \\
\hline
\end{tabular}


Continued Table 1. Vegetation indices calculated from Sentinel-2 satellite imagery

\begin{tabular}{|c|c|c|c|c|}
\hline 1 & 2 & 3 & 4 & 5 \\
\hline Application & Index & Description & Equation & Reference \\
\hline \multirow{3}{*}{$\begin{array}{l}\text { Assessment of the } \\
\text { general condition of } \\
\text { vegetation }\end{array}$} & TTVI & $\begin{array}{l}\text { Thiam's Transformed } \\
\text { Vegetation Index }\end{array}$ & $\mathrm{TTVI}=\sqrt{|\mathrm{NDVI}+0.5|}$ & Thiam, 1997 \\
\hline & TVI & $\begin{array}{l}\text { Transformed Vegetation } \\
\text { Index }\end{array}$ & $\begin{aligned} \text { MSAVI2 }=\frac{1}{2}[ & 120 *\left(R_{750}-R_{550}\right)-200 * \\
& \left.\left(R_{670}-R_{550}\right)\right]\end{aligned}$ & Deering, 1975 \\
\hline & WDVI & $\begin{array}{l}\text { Weighted Difference } \\
\text { Vegetation Index }\end{array}$ & WDVI $=\mathrm{R}_{\mathrm{NIR}}-\mathrm{a} * \mathrm{R}_{\mathrm{red}}$ & $\begin{array}{c}\text { Richardson, } \\
1977\end{array}$ \\
\hline \multirow{5}{*}{$\begin{array}{l}\text { Assessment of } \\
\text { photosynthetically } \\
\text { active pigment }\end{array}$} & CLG & Chlorophyll Index Green & $\mathrm{CLG}=\frac{R_{\text {NIR }}}{R_{\text {green }}}-1$ & $\begin{array}{l}\text { Gitelson, } \\
2003\end{array}$ \\
\hline & CLRE & $\begin{array}{l}\text { Red-edge-band Chlorophyll } \\
\text { Index }\end{array}$ & $\mathrm{CLRE}=\frac{R_{750}}{R_{710}}-1$ & $\begin{array}{l}\text { Gitelson, } \\
2003\end{array}$ \\
\hline & MCARI & $\begin{array}{l}\text { Modified Chlorophyll } \\
\text { Absorption Ratio Index }\end{array}$ & $\begin{array}{c}\mathrm{MCARI}=\left[\left(R_{700}-R_{670}\right)-0.2 *\left(R_{700}-R_{550}\right)\right] * \\
\left(R_{700} / R_{670}\right)\end{array}$ & $\begin{array}{l}\text { Daughtery, } \\
2000\end{array}$ \\
\hline & $\mathrm{MTCl}$ & $\begin{array}{l}\text { MERIS Terrestrial } \\
\text { Chlorophyll Index }\end{array}$ & $\mathrm{MTCI}=\frac{R_{754}-R_{709}}{R_{709}-R_{681}}$ & $\begin{array}{l}\text { Dash And } \\
\text { Curran, } 2004\end{array}$ \\
\hline & S2REP & $\begin{array}{l}\text { Sentinel-2 Red-Edge } \\
\text { Position Index }\end{array}$ & $\mathrm{S} 2 \mathrm{REP}=705+35 * \frac{\left(\left(R_{N I R}+R_{r e d}\right) / 2\right)-R_{705}}{\left(R_{740}-R_{705}\right)}$ & $\begin{array}{l}\text { Frampton et } \\
\text { al., } 2013\end{array}$ \\
\hline \multirow{2}{*}{$\begin{array}{l}\text { Assessment of the } \\
\text { amount of light used } \\
\text { in photosynthesis }\end{array}$} & SIPI & $\begin{array}{l}\text { Structure Insensitive } \\
\text { Pigment Index }\end{array}$ & $\mathrm{SIPI}=\frac{R_{800}-R_{450}}{R_{800}+R_{650}}$ & $\begin{array}{l}\text { Peñuelas et } \\
\text { al., } 1995\end{array}$ \\
\hline & ZMI & Zarco-Tejada \& Miller Index & $\mathrm{ZMI}=\frac{R_{750}}{R_{710}}$ & $\begin{array}{l}\text { Zarco-Tejada } \\
\text { et al., } 2001\end{array}$ \\
\hline \multirow{5}{*}{$\begin{array}{l}\text { Assessment of water } \\
\text { content }\end{array}$} & DSWI & $\begin{array}{l}\text { Disease Water Stress } \\
\text { Index }\end{array}$ & DSWI $=\frac{R_{802}+R_{547}}{R_{1657}+R_{682}}$ & $\begin{array}{l}\text { Galvão et al., } \\
2005\end{array}$ \\
\hline & MNDWI & $\begin{array}{c}\text { Modified Normalized } \\
\text { Difference Water Index }\end{array}$ & $\mathrm{MNDWI}=\frac{R_{\text {green }}-R_{M I R}}{R_{\text {green }}+R_{M I R}}$ & Xu, 2006 \\
\hline & NDWI & $\begin{array}{l}\text { Normalized Difference } \\
\text { Water Index }\end{array}$ & $\mathrm{NDWI}=\frac{R_{\text {green }}-R_{N I R}}{R_{\text {green }}+R_{N I R}}$ & $\begin{array}{l}\text { McFeeters, } \\
1996\end{array}$ \\
\hline & NDWI2 & $\begin{array}{l}\text { Normalized Difference } \\
\text { Water } 2 \text { Index }\end{array}$ & $\mathrm{NDWI} 2=\frac{R_{857}-R_{1241}}{R_{857}+R_{1241}}$ & Gao, 1996 \\
\hline & NDII & $\begin{array}{l}\text { Normalized Difference } \\
\text { Infrared Index }\end{array}$ & $\mathrm{NDII}=\frac{R_{850}-R_{1650}}{R_{850}+R_{1650}}$ & $\begin{array}{l}\text { Hardisky et } \\
\text { al., } 1993\end{array}$ \\
\hline
\end{tabular}

Source: own elaboration

the runs noted by Masialeti et al. (2010) and Pan et al. (2015), thus, they appear to be characteristic for maize and sugar beet crops. For maize, the NDII value was 0.19 in 2018 , and 0.29 in 2019 . While the NDVI reached 0.66 and 0.73 in 2018 and 2019 , respectively, at the stem elongation stage. For sugar beets at the rosette growth stage, we observed an NDII of 0.45 in 2018 and 0.38 in 2019, while the NDVI values reach 0.83 in 2018 and 0.75 in 2019. Estimates of the ratio of carotenoids to chlorophyll can be followed using the SIPI (structural independent pigment index) curves. The distinctly increased values observed for maize at heading and sugar beets at the beets' root development stage in 2019 confirm that the vegetation was stressed (Kycko et al. 2019a).
Assessing the land surface temperatures derived from the lowresolution satellite data, we noticed a consistency in the Sentinel-3 temperature registrations from all nineteen maize fields as well as from all ten sugar beet fields. The Sentinel-3 LST mean and median values extracted from included crop fields were highly consistent; for example, the average difference between the mean and median $\left(\Delta_{\text {mean, median }}\right)$ across all the Sentinel-3 satellite registrations of maize for 2018 was $0.42^{\circ} \mathrm{C}$ (Fig. 5), whereas the averaged $\Delta_{\text {mean, median }}$ from the satellite observations in 2019 was $0.17^{\circ} \mathrm{C}$ (Fig. 5). Next, the average difference between the mean and median Sentinel-3 LST for sugar beet in 2018 was $0.36^{\circ} \mathrm{C}$ (Fig. 5). In contrast, the land surface temperatures averaged 
MISCELLANEA GEOGRAPHICA - REGIONAL STUDIES ON DEVELOPMENT

Vol. $25 \cdot$ No. 4 • $2021 \cdot$ pp. 226-237 •ISSN: 2084-6118 • DOI: 10.2478/mgrsd-2020-0029

Table 2. Sentinel-3 cloud-free satellite images of croplands in Wielkopolska. Actual state on 10. September 2019.

\begin{tabular}{|c|c|c|c|c|c|c|c|c|c|c|c|c|c|c|c|c|c|c|c|c|c|c|c|c|c|}
\hline Year & \multicolumn{8}{|c|}{2018} & \multicolumn{17}{|c|}{2019} \\
\hline Month & \multicolumn{3}{|c|}{ July } & \multicolumn{5}{|c|}{ August } & \multicolumn{4}{|c|}{ July } & \multicolumn{13}{|c|}{ August } \\
\hline Day & 5 & 9 & 21 & 28 & 1 & 5 & 13 & 17 & 4 & 15 & 25 & 26 & 1 & 8 & 12 & 13 & 15 & 22 & 23 & 24 & 26 & 28 & 29 & 30 & 31 \\
\hline
\end{tabular}

Source: own elaboration
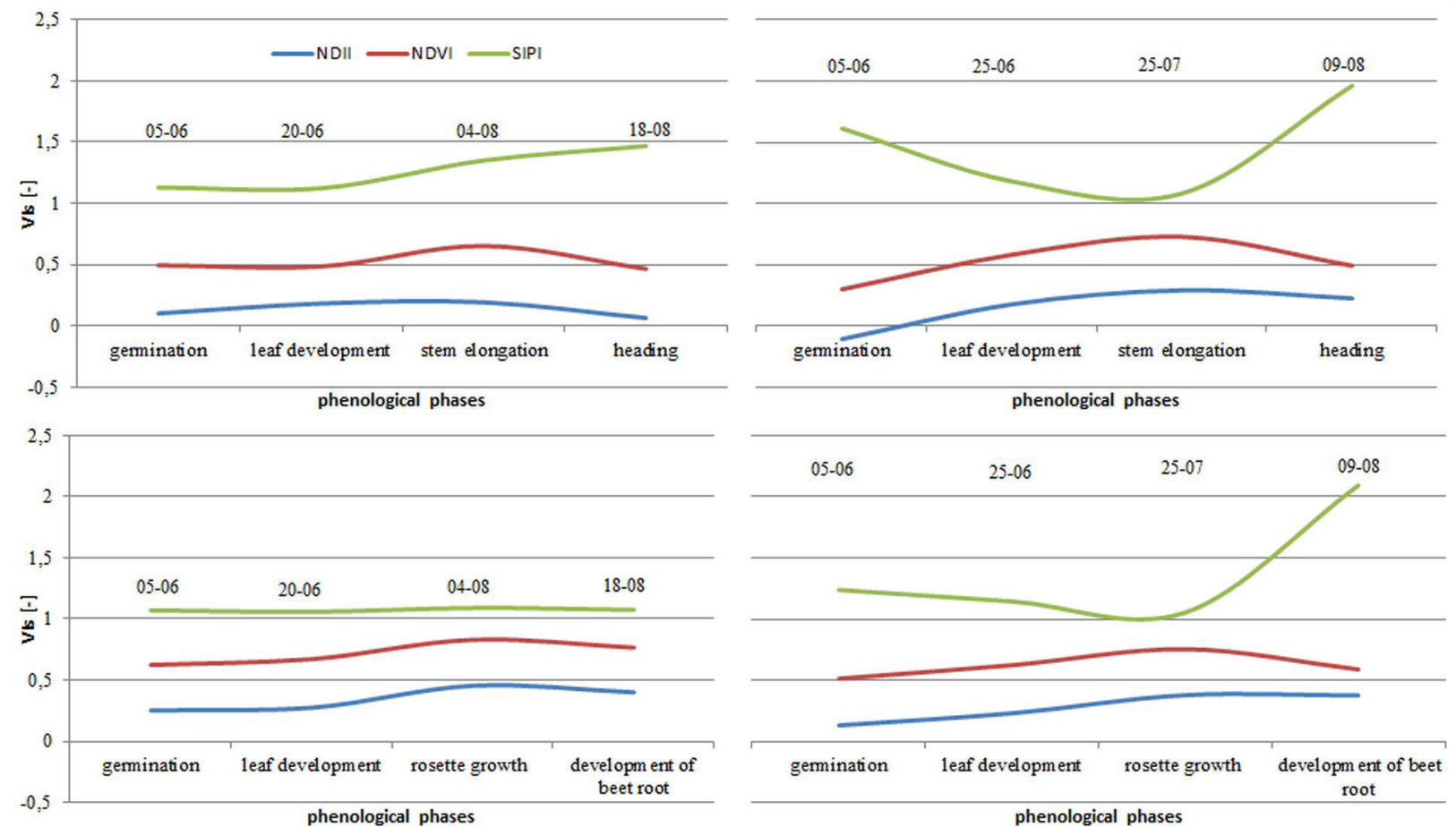

Figure 4. Time series of vegetation indices for maize and sugar beets during 2018-2019 Source: own elaboration

$\Delta_{\text {mean, median }}$ in 2019 for sugar beet fields was $0.24^{\circ} \mathrm{C}$ (Fig. 5). The greater consistency of satellite temperature registrations during 2019 compared to 2018 could be the effect of long-term and stable drought conditions over the whole study area (Fig. 6, Fig. 7). Having determined the change in conditions over two years, we were able to draw conclusions about the influence of weather conditions on vegetation's state.

At the beginning of July 2018 we noticed higher maximum air temperatures, reaching $30^{\circ} \mathrm{C}$, in contrast to the first days of July 2019, which had maximum air temperatures of around $20^{\circ} \mathrm{C}$. We also observed corresponding changes in surface temperatures for the same period (Fig. 5). Spring and summer 2018 were characterized by short and intense periods of rain, with a total precipitation of $40-50 \mathrm{~mm}$ during one week; as well as periods of heat (Fig. 6) that may have significantly worsened drought conditions by hastening water evaporation and thermal stress on crops. During summer 2019 we noticed that precipitation was evenly distributed, with a total of 15-20 $\mathrm{mm}$ of rain every week (Fig. 7). On the other hand, we noted periodical cycles in surface temperatures. Thus the favorable meteorological conditions before the growing season in 2019 implied the stable growth of maize and sugar beets until August, when we noticed stressed vegetation, confirmed by clearly increased SIPI values (Fig. 4).
The low NDII and high SIPI values noted during the last phenological phases were associated with climatic factors such as an increased surface temperature and response to drought conditions.

At the next stage of the work, correlation analysis was performed comparing particular VIs derived from satellite images and those ChIF values measured on the ground in order to find if a significant relationship existed between these two parameters. Assessments of $\mathrm{Fv} / \mathrm{Fm}$ from VIs derived from remote sensing data have been reported by several studies (Tan et al. 2012; Peng et al. 2017; Kycko et al. 2019a; Kycko et al. 2019b; Wei et al. 2019; Zagajewski et al, 2017; Zagajewski et al. 2018). For instance, some researchers compared the results of VIs to assess the Fv/Fm of maize, and reached the conclusion that out of the various kinds of VI that had a close relationship with Fv/Fm, SIPI performed best (Tan et al, 2012). If ground cover was significant, the impact of the background was significantly reduced, and $\mathrm{Fv} / \mathrm{Fm}$ could be better estimated using NDVI (Wei et al. 2019). Kycko et al. (2019a) and Zagajewski et al. (2018) used in-situ hyperspectral remote sensing as an important technique to fulfill real-time monitoring of plant condition based on its superior performance in acquiring vegetation canopy information rapidly and non-destructively. In studies conducted by Peng et. al. (2017) an approach was demonstrated to estimate ChIF using spectral indices calculated 

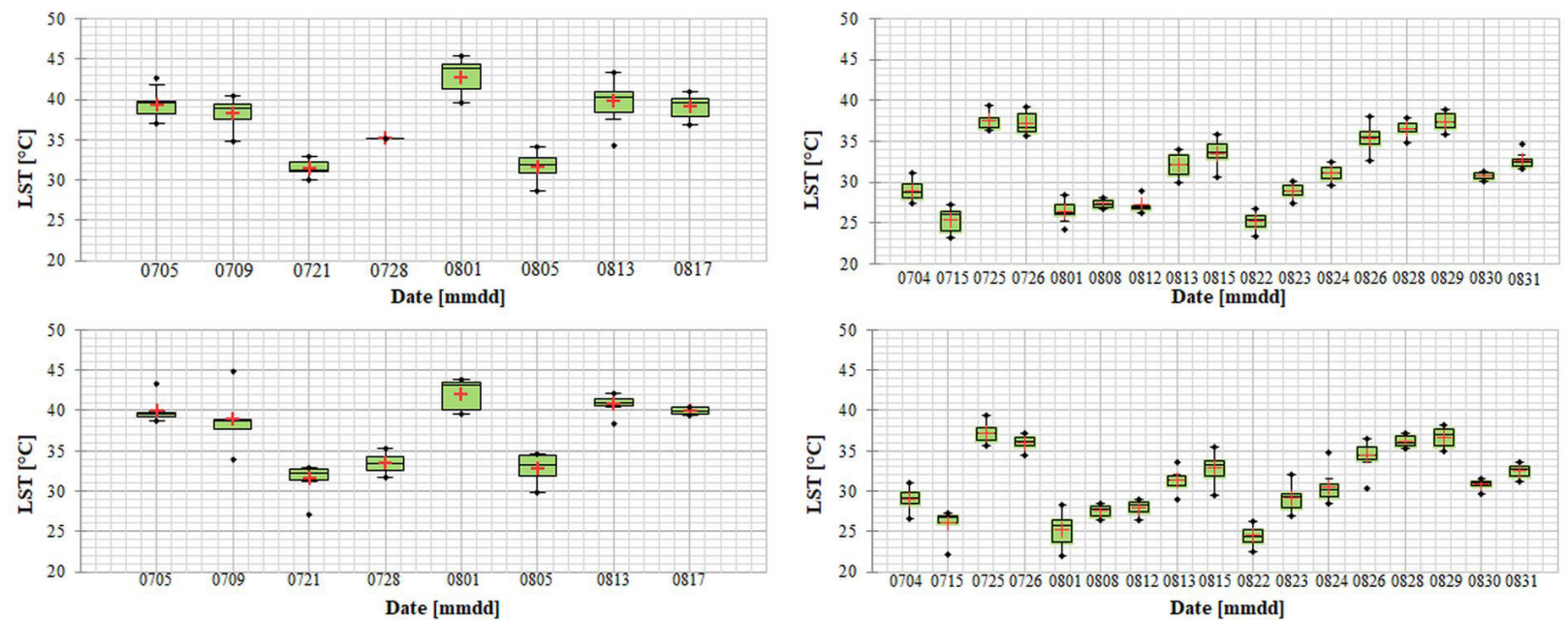

Figure 5. Sentinel-3 based land surface temperatures of maize and sugar beets during 2018-2019. The red crosses indicate mean, thin black lines median, green boxes $25 \%-75 \%$ ranges, black dots are outliers

Source: own elaboration

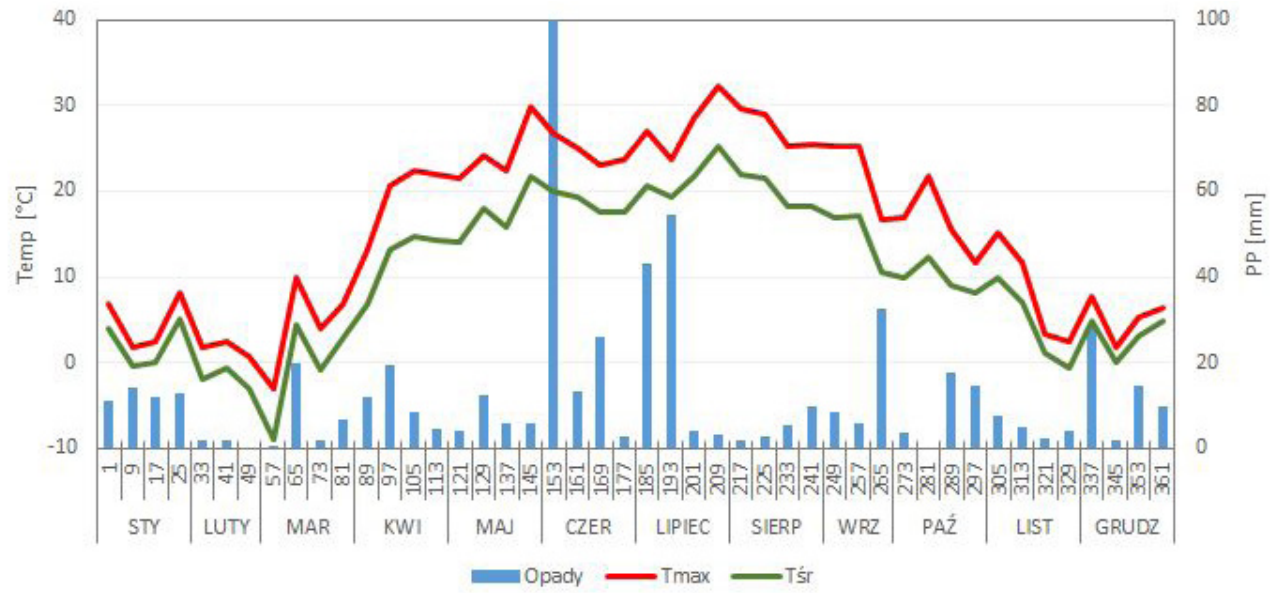

Figure 6. Maximum and mean temperatures, as well as total precipitation, noted in 2018 at the meteorological station in the town of Kornik Source: own elaboration

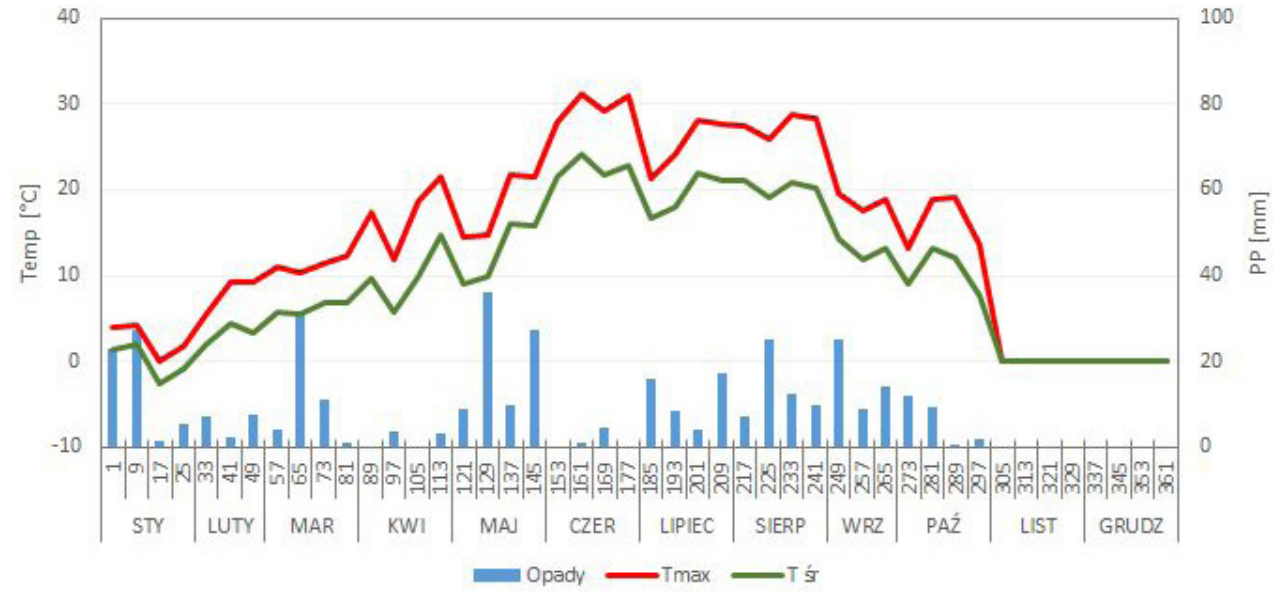

Figure 7. Maximum and mean temperature, as well as total precipitation, noted in 2019 at the meteorological station in the town of Kornik Source: own elaboration 
MISCELLANEA GEOGRAPHICA - REGIONAL STUDIES ON DEVELOPMENT

Vol. $25 \cdot$ No. $4 \cdot 2021 \cdot$ pp. 226-237 •ISSN: 2084-6118 • DOI: 10.2478/mgrsd-2020-0029

Table 3. Results of correlation analysis of ground measured ChIF and Vis (red color - results with the highest correlation coefficient)

\begin{tabular}{|c|c|c|c|c|c|c|c|c|c|}
\hline \multirow[b]{2}{*}{ Assessment } & \multirow{2}{*}{$\begin{array}{l}\text { Vegetation } \\
\text { Index }\end{array}$} & \multicolumn{4}{|c|}{ Maize } & \multicolumn{4}{|c|}{ Sugar beets } \\
\hline & & $\begin{array}{c}\mathbf{R} \\
\text { coefficient }\end{array}$ & MAE & RMSE & $p$-value & $\begin{array}{c}R \\
\text { coefficient }\end{array}$ & MAE & RMSE & $p$-value \\
\hline \multirow{21}{*}{$\begin{array}{l}\text { Assessment of the } \\
\text { general condition of } \\
\text { vegetation }\end{array}$} & CTVI & 0.19 & 0.08 & 0.07 & 0.445 & 0.36 & 0.08 & 0.07 & 0.204 \\
\hline & DVI & 0.24 & 0.07 & 0.07 & 0.315 & 0.29 & 0.08 & 0.08 & 0.320 \\
\hline & EVI & 0.61 & 0.03 & 0.03 & 0.005 & 0.45 & 0.05 & 0.04 & 0.106 \\
\hline & GEMI & -0.26 & 0.07 & 0.07 & 0.275 & -0.25 & 0.08 & 0.08 & 0.394 \\
\hline & GNDVI & 0.07 & 0.10 & 0.09 & 0.767 & 0.35 & 0.09 & 0.09 & 0.226 \\
\hline & IRECI & 0.64 & 0.02 & 0.02 & 0.003 & 0.22 & 0.08 & 0.08 & 0.447 \\
\hline & MSAVI & 0.17 & 0.08 & 0.07 & 0.478 & 0.37 & 0.07 & 0.06 & 0.188 \\
\hline & MSAVI2 & 0.17 & 0.08 & 0.07 & 0.478 & 0.37 & 0.07 & 0.06 & 0.188 \\
\hline & NDREI1 & 0.14 & 0.08 & 0.07 & 0.579 & 0.35 & 0.07 & 0.07 & 0.213 \\
\hline & NDREI2 & 0.06 & 0.10 & 0.09 & 0.815 & 0.35 & 0.07 & 0.07 & 0.223 \\
\hline & NDVI & 0.19 & 0.08 & 0.08 & 0.429 & 0.35 & 0.07 & 0.07 & 0.214 \\
\hline & NRVI & -0.19 & 0.08 & 0.08 & 0.429 & -0.35 & 0.07 & 0.07 & 0.214 \\
\hline & REIP & 0.15 & 0.08 & 0.07 & 0.538 & 0.31 & 0.08 & 0.07 & 0.284 \\
\hline & RVI & -0.17 & 0.08 & 0.07 & 0.478 & -0.37 & 0.07 & 0.07 & 0.188 \\
\hline & SATVI & 0.22 & 0.07 & 0.07 & 0.362 & 0.40 & 0.05 & 0.05 & 0.152 \\
\hline & SAVI & 0.56 & 0.04 & 0.03 & 0.012 & 0.32 & 0.08 & 0.07 & 0.269 \\
\hline & SLAVI & 0.37 & 0.06 & 0.06 & 0.124 & 0.26 & 0.08 & 0.07 & 0.374 \\
\hline & SR & 0.29 & 0.07 & 0.06 & 0.233 & 0.21 & 0.08 & 0.08 & 0.479 \\
\hline & TTVI & 0.19 & 0.08 & 0.07 & 0.445 & 0.36 & 0.07 & 0.07 & 0.478 \\
\hline & TVI & 0.55 & 0.04 & 0.04 & 0.015 & 0.21 & 0.08 & 0.08 & 0.478 \\
\hline & WDVI & 0.24 & 0.07 & 0.06 & 0.315 & 0.29 & 0.08 & 0.07 & 0.320 \\
\hline \multirow{5}{*}{$\begin{array}{l}\text { Assessment of } \\
\text { photosynthetically } \\
\text { active pigment }\end{array}$} & CLG & 0.06 & 0.10 & 0.10 & 0.805 & 0.24 & 0.07 & 0.07 & 0.401 \\
\hline & CLRE & 0.09 & 0.10 & 0.09 & 0.708 & 0.28 & 0.08 & 0.07 & 0.335 \\
\hline & MCARI & 0.35 & 0.06 & 0.06 & 0.141 & 0.26 & 0.07 & 0.06 & 0.377 \\
\hline & $\mathrm{MTCl}$ & -0.01 & 0.11 & 0.10 & 0.980 & 0.38 & 0.06 & 0.06 & 0.186 \\
\hline & S2REP & 0.46 & 0.06 & 0.05 & 0.046 & 0.43 & 0.05 & 0.04 & 0.125 \\
\hline \multirow{2}{*}{$\begin{array}{l}\text { Assessment of the } \\
\text { amount of light used in } \\
\text { photosynthesis }\end{array}$} & SIPI & -0.68 & 0.02 & 0.02 & 0.001 & 0.24 & 0.07 & 0.07 & 0.401 \\
\hline & ZMI & 0.54 & 0.04 & 0.04 & 0.017 & -0.13 & 0.09 & 0.08 & 0.665 \\
\hline \multirow{5}{*}{$\begin{array}{c}\text { Assessment of water } \\
\text { content }\end{array}$} & DSWI & 0.64 & 0.03 & 0.03 & 0.003 & 0.22 & 0.07 & 0.06 & 0.460 \\
\hline & MNDWI & 0.54 & 0.04 & 0.04 & 0.017 & 0.09 & 0.09 & 0.09 & 0.751 \\
\hline & NDWI & -0.07 & 0.10 & 0.09 & 0.767 & -0.35 & 0.06 & 0.06 & 0.226 \\
\hline & NDWI2 & 0.37 & 0.06 & 0.06 & 0.120 & 0.33 & 0.07 & 0.06 & 0.251 \\
\hline & NDII & 0.65 & 0.03 & 0.03 & 0.002 & 0.31 & 0.07 & 0.07 & 0.279 \\
\hline
\end{tabular}

Source: own elaboration

from leaf reflectance measured using a hyperspectral radiometer, however, the reflectance spectra were resampled to simulate the spectral bands of the MSI aboard Sentinel-2.

Correlation analysis was performed between ground measured ChIF and VIs derived from Sentinel-2 images (Table 3).

The results obtained are supported by the phenological behavior of the maize and sugar beets, which is related to water content and the efficiency of photosynthesis (Rolph 1873; Plessis 2003). For maize, the highest correlation between ground measured ChIF and VIs appears for NDII ( $r=0.65$ ), and at a negative correlation for SIPI $(r=-0.68)$. Similar ranges of correctness were achieved by Kycko et. al. (2019b) when analyzing the influence of lead ions on the growth of pea plants. Tan et. al. (2012) reported that SIPI was the most sensitive remote sensing variable for monitoring $\mathrm{Fv} / \mathrm{Fm}$, with a correlation coefficient of $r=-$ 0.88 . These reflectance indices should be effective for estimating ChIF in respective crops by using simple reflectance techniques (Peñuelas \& Filella 1998; Kycko et al. 2014). High correlations were 
Table 4. Linear regression equations for estimating $\operatorname{ChIF}\left(F_{/} / F_{M}\right)$

\begin{tabular}{|c|c|c|}
\hline $\begin{array}{c}\text { CROP } \\
\text { TYPE }\end{array}$ & INDEX & FORMULA \\
\hline \multirow{2}{*}{ MAIZE } & NDII & $\mathrm{F}_{\mathrm{V}} / \mathrm{F}_{\mathrm{M}}=0.68053+0.25102 * \mathrm{NDII}$ \\
\cline { 2 - 3 } & $\mathrm{SIPI}$ & $\mathrm{F}_{\mathrm{V}} / \mathrm{F}_{\mathrm{M}}=1.1527-0.3640 * \mathrm{SIPI}$ \\
\hline \multirow{2}{*}{$\begin{array}{c}\text { SUGAR } \\
\text { BEETS }\end{array}$} & $\mathrm{EVI}$ & $\mathrm{F}_{\mathrm{V}} / \mathrm{F}_{\mathrm{M}}=0.60230+0.07402 * \mathrm{EVI}$ \\
\cline { 2 - 3 } & $\mathrm{S} 2 \mathrm{REP}$ & $\mathrm{F}_{\mathrm{V}} / \mathrm{F}_{\mathrm{M}}=-8.753+0.01317 * \mathrm{~S} 2 \mathrm{REP}$ \\
\hline
\end{tabular}

Source: own elaboration

also obtained for VIs that contained various wavelengths. Some of the most significant ranges overlapped with the research by Zagajewski et al., (2018) for Bistorta vivipara: SIPI ( $r=-0.46)$ and ZMI ( $r=0.61$ ). Alternatively Zagajewski et al. (2017) used RapidEye satellite imagery to assess how well satellite data can detect vegetation stress on the ground. However, a simple ratio, such as NDVI, is characterized by low correlations and seem to be insufficient for detecting drought in plant condition (Zarco-Tejada et al. 2013; Liu et al. 2018). Moreover, analyses made on spectra collected in the SWIR region (1400-1550 nm and 1850-2000 $\mathrm{nm}$ ) using airborne or satellite platforms are problematic due to the effects on measured signals of atmospheric water vapor (Zagajewski et al. 2017; Hillnhütter et al. 2011). The least significant relation between ChIF and VIs exist for sugar beets. Despite this, it should be noted that the highest correlation appears for EVI $(r=0.45)$ and S2REP $(r=0.43)$. The impact of single stresses, such as water deficit or drought, could be detected. However, a similar decrease in fluorescence intensity hindered the differentiation between both stresses. This fact was an overall obstacle in our study and was also observed for combined stresses. One possible explanation for these observations is that all chosen stresses reduce plant photosynthetic efficiency and the differentiation becomes more complicated due to the interaction between the specific processes of the individual stresses (Leufen et al. 2014). The results of the 2013 study by Li et. al. show that sugar beets tolerate tissue dehydration better, and can be distinguished from sensitive sugar beets that rely on the efficiency of electron transport in PSII.

The regression equations derived from the correlation analysis served to determine ChIF values on the basis of particular vegetation indices. The formulas for the linear regression equations used to estimate ChIF $\left(F_{v} / F_{M}\right)$ are given in Table 4. Next, ChIF values, calculated based on the satellite VIs for control points, were compared with those measured on the ground in order to estimate the accuracy of the ChIF determination.

The root mean square error (RMSE) for the predicted ChIF $\left(F_{V} / F_{M}\right)$ from NDII was 0.033 , and from SIPI was 0.032 for maize. While the RMSE for sugar beets was the same for both indices (EVI and S2REP) and equal to 0.038. Tan et al. (2012) achieved similar results measuring maize using a model established on the basis of SIPI, in which the RMSE was 0.082. However, EVI and NDVI noted by Wei et. al (2019), showed an RMSE below 0.148 .

\section{Conclusions}

Reflectance indices such as structural independent pigment index (SIPI) and normalized difference infrared index (NDII), which are related to pigment and water content, may be useful in assessing ChIF. This adds new possibilities for indirectly assessing progressive leaf water stress. Average values of ChIF showed significant reductions under relatively serious drought, while simple VI means did not show any remarkable change until there was extreme drought. Our results confirmed the relations between ChIF measured at field sites and ChIF retrieved from satellite data. Therefore ChIF high-temporal satellite retrievals provide an opportunity for following changes in ChIF and finding the effects of drought stress on ChIF changes. The study of the relationships between reference chlorophyll fluorescence and vegetation indices derived from Sentinel-2 images led to the conclusion that there is quite a significant relation between these two types of data. Both indices - SIPI and NDII - derived from the Sentinel-2 during the maize vegetation season correlated well with ground measured fluorescence $(r=-0.68$ and $r=0.65$ respectively). Moreover the temporal dynamics of SIPI and NDII reflect the surface temperature changes and meteorological conditions existing during the crucial phase of the growing season, especially at the end of July and August. This means that Sentinel-2 satellite data can be applied to monitoring stress conditions during the growing season. Nevertheless, it should be mentioned that the significant impact of drought conditions in 2018 and 2019 was observed for sugar beets, while analysis of the Sentinel-2 based vegetation indices and in-situ measured ChIF revealed lower correlation, at $r=0.43$ for S2REP and $r=0.46$ for EVI. The results confirmed that both VIs - EVI and S2REP - are reliable indicators for monitoring maize and sugar beet conditions related to chlorophyll content.

EVI and S2REP indices are desirable indicators for monitoring photosynthesis (or chlorophyll content), while the SIPI index (related to the amount of active light) and NDII (related to water content) better reflect stress conditions and ChIF. High SIPI values (increased carotenoids and decreased chlorophyll) are often an indicator of plant disease, which is associated with loss of chlorophyll in plants. Therefore, there is a negative correlation with the SIPI index, which provides information about stress conditions. The worst results in sugar beets may be caused by the fact that the signal acquired by the satellites was not homogeneous. Sugar beet leaves do not cover soil background signals, while the top canopy of maize cover the bare soil under them, especially in areas of dense canopy.

The results of this study indicate further research is needed, which should be based on a synergy of low and high resolution satellite data; these data will enable a more detailed analysis for estimating fluorescence and its relation to climatic conditions, environmental aspects, and indices derived from satellite images, taking into account the variability of other crop fields within the study area. In the near future, we expect that retrieval algorithms will become operational that allow the fluorescence for crop stress condition monitoring and crop estimation to be quantified.

\section{ORCID}

Radosław Gurdak (D) https://orcid.org/0000-0001-8991-7306 Maciej Bartold (10) https://orcid.org/0000-0003-1058-0304 


\section{References}

Baligar, VC, Fageria, NK, \& He, ZL 2001, 'Nutrient use efficiency in plants', Communications in Soil Science and Plant Analysis, 32(7-8), pp. 921-950.

Bochenek, Z, Dabrowska-Zielińska, K, Gurdak, R, Niro, F, Bartold, M \& Grzybowski, P 2017, 'Validation of the LAI biophysical product derived from Sentinel-2 and Proba-V images for winter wheat in western Poland', Geoinformation Issues, vol. 9, No 1(9), pp. 15-26. doi:10.34867/gi.2017.2

Chaves, MM, Maroco, JP \& Pereira, JS 2003 'Understanding plant responses to drought - from genes to the whole plant', Functional Plant Biology, vol. 30(3), pp. 239-264.

Claasen, MM \& Shaw, RH 1970 'Water deficit effects on grain. II. Grain components', Agron. J., vol. 62, pp. 652-655.

Damm, A, Guanter, L, Paul-Limoges, E, van der Tol, C, Hueni, A, Buchmann, N, Eugster, W, Ammann, C \& Schaepman, ME 2015, 'Far-red sun-induced chlorophyll fluorescence shows ecosystem-specific relationships to gross primary production: an assessment based on observational and modeling approaches', Remote Sensing of Environment, vol. 166, pp. 91-105.

Dąbrowska-Zielińska, K, Ciołkosz, A, Malińska, A \& Bartold, M 2011, 'Monitoring of agricultural drought in Poland using data derived from environmental satellite images', Geoinformation Issues, vol. 3, no. 1(3), pp. 87-97. doi: 10.34867/gi.2011.7

Doorenbos, J \& Kassam, AK 1979, 'Yield response to water', Irrigation and Drainage Paper, vol 33, FAO, United Nations, Rome, pp. 176.

Drusch, M, Moreno, J, Del Bello, U, Franco, R, Goulas, Y, Huth A, Kraft, S, Middleton, EM, Miglietta, F \& Mohammed, G 2017. 'The FLuorescence EXplorer Mission Concept-ESA's Earth Explorer 8', IEEE Trans. Geosci. Remote Sens., vol. 55, pp. $1273-1284$

Fernandez-Armesto, F 2011, The World: A History, Penguin Academics, pp. 470.

Garrod, JF 1974, 'The role of gibberellins in early growth and development of sugar beet', Journal of Experimental Botany, vol. 25(5), pp. 945-954. doi:10.1093/jxb/25.5.945

Genty, B, Briantais, JM \& Baker, NR 1989, 'The relationship between the quantum yield of photosynthetic electron transport and quenching of chlorophyll fluorescence' BBA Gen Subj, 990, pp. 87-92

Gobron, N, Pinty, B, Taberner, M, Mélin, F, Verstraete, MM \& Widlowski, JL 2006, 'Monitoring the photosynthetic activity of vegetation from remote sensing data', Advances in Space Research, vol. 38(10), pp. 2196-2202. doi:10.1016/j. asr.2003.07.079

Gurdak, R, Grzybowski, P 2018, 'Feasibility study of vegetation indices derived from Sentinel-2 and PlanetScope satellite images for validating the LAI biophysical parameter to monitoring development stages of winter wheat', Geoinformation Issues, vol. 10, No 1 (10), pp. 27-35. doi:10.34867/gi.2018.3

Hillnhütter, C, Mahlein, AK, Sikora, RA \& Oerke EC 2011, 'Remote sensing to detect plant stress induced by Heterodera schachtii and Rhizoctonia solani in sugar beet fields', Field Crops Research, 122, pp. 70-77, doi:10.1016/j. fcr.2011.02.007Jones, HG 1992, 'Plants and microclimate: a quantitative approach to environmental plant physiology', Cambridge University Press.

Kancheva, RH, Borisova, IT \& Iliev, IT 2008, 'Chlorophyll fluorescence as a plant stress indicator', Proceedings of the $5^{\text {th }}$ National Conference, Space Research Institute
-Russian Academy of Sciences, Azbuka-2000 Ltd., Moscow, vol.5 (T.2), pp. 301-306

Kitajima, M \& Butler, WL 1975, 'Quenching of chlorophyll fluorescence and primary photochemistry in chloroplasts by dibromothymoquinone', Biochimica et Biophysica Acta, vol. 376, pp. 105-115.

Kranner, I., Minibayeva, FV., Beckett, RP., \& Seal, CE 2010, 'What is stress? Concepts, definitions and applications in seed science', New Phytologist, vol. 188(3), pp. 655-673, doi:10.1111/j.1469-8137.2010.03461.x

Kycko, M, Zagajewski, B \& Kozłowska A 2014, 'Variability in spectral characteristics of trampled high-mountain grasslands', Miscellanea Geographica, vol. 18(2), pp. 10-14.

Kycko M 2017, Assessment of the dominant alpine sward species condition of the Tatra National Park using hyperespectral remote sensing, University of Warsaw, $\mathrm{PhD}$ thesis.

Kycko, M, Zagajewski, B, Lavender, S \& Dabija, A 2019a, 'In situ hyperspectral remote sensing for monitoring of Alpine Trampled and Recultivated species', Remote Sensing, vol. 11(11), 1296, pp. 1-24, doi:10.3390/rs11111296

Kycko, M, Romanowska, E \& Zagajewski, B 2019b, 'Lead-Induced Changes in Fluorescence and Spectral Characteristics of Pea Leaves', Remote Sensing, vol. 11(1885), pp. 1-21, doi:10.3390/rs11161885.

Leufen, G, Noga, G \& Hunsche, M 2014, 'Fluorescence indices for the proximal sensing of powdery mildew, nitrogen supply and water deficit in sugar beet leaves', Agriculture, vol. 4(2), pp. 58-78, doi:10.3390/agriculture4020058

Li, X, Xiao, J, He, B, Altaf Arain, M, Beringer, J, Desai, AR, Emmel, C, Hollinger, DY, Krasnova, A \& Mammarella, I 2018, 'Solarinduced chlorophyll fluorescence is strongly correlated with terrestrial photosynthesis for a wide variety of biomes: First global analysis based on OCO-2 and flux tower observations', Global Change Biology, vol. 24, pp. 3990-4008.

Li, GL, Wu, HX, Sun, YQ \& Zhang, SY, 2013, 'Response of chlorophyll fluorescence parameters to drought stress in sugar beet seedlings'. Russian Journal of Plant Physiology, 60(3), pp. 337-342, doi:10.1134/s1021443713020155Liu, L, Yang, X, Zhou, H, Liu, S, Zhou, L, Li, X \& Wu, J 2018, 'Evaluating the utility of solar-induced chlorophyll fluorescence for drought monitoring by comparison with NDVI derived from wheat canopy', Science of The Total Environment, vol. 625, pp. 1208-1217, doi:10.1016/j.scitotenv.2017.12.268

López-Lozano, R, Duveiller, G, Seguini, L, Meroni, M, GarcíaCondado, S, Hooker, J, Leo, O \& Baruth, B 2015, 'Towards regional grain yield forecasting with $1 \mathrm{~km}$-resolution EO biophysical products: Strengths and limitations at panEuropean level', Agric. For. Meteorol., vol. 206, pp. 12-32.

McFarlane, JC, Watson, RD, Theisen, AF, Jackson, RD, Ehrler, WL, Pinter, PJ, Idso, SB \& Reginato, RJ 1980, 'Plant stress detection by remote measurement of fluorescence'.. Appl. Opt., vol. 19, pp. 3287-3289

Masialeti, I, Egbert, S \& Wardlow, BD 2010, 'A comparative analysis of phenological curves for major crops in Kansas', GIScience \& Remote Sensing, vol. 47(2), pp. 241-259. doi:10.2747/1548-1603.47.2.241

Mathobo, R, Marais, D \& Steyn, JM 2017, 'The effect of drought stress on yield, leaf gaseous exchange and chlorophyll fluorescence of dry beans (Phaseolus vulgaris L.)', Agricultural Water Management, vol. 180, pp. 118-125.

Maxwell, K \& Johnson, GN 2000, 'Chlorophyll fluorescence - a practical guide', Journal of Experimental Botany, vol. 51, no. 345, pp. 659-668. 
Meroni, M, Rossini, M, Guanter, L, Alonso, L, Rascher, U, Colombo, R \& Moreno, J 2009, 'Remote sensing of solarinduced chlorophyll fluorescence: Review of methods and applications', Remote Sensing, vol. 113, pp. 2037-2051.

Miguel Costa, J, Grant, OM, \& Chaves, MM 2013, 'Thermography to explore plantenvironment interactions', Journal of Experimental Botany, vol. 64(13), pp. 3937-3949.

Mohammeda, GH, Colombo, R, Middleton, EM, Rascherd, U, van der Tol, C, Nedbald, L, Goulasf, Y, Pérez -Priego, O, Damm, A, Meroni, M, Joiner, J, Cogliati, S, Verhoef, W, Malenovský, Z, Gastellu-Etchegorry, JP, Miller, JR, Guanter, L, Moreno, J, Moya, I, Berry, JA, Frankenberg, Ch \& Zarco-Tejada, J 2019, 'Remote sensing of solar-induced chlorophyll fluorescence (SIF) in vegetation: 50 years of progress', Remote Sensing of Environment, vol. 231, pp. 111-177, doi:10.1016/j.rse.2019.04.030

Pan, Z, Huang, J., Zhou, Q, Wang, L, Cheng, Y, Zhang, H \& Liu, J 2015, 'Mapping crop phenology using NDVI time-series derived from HJ-1 A/B data', International Journal of Applied Earth Observation and Geoinformation, vol. 34, pp. 188197. doi:10.1016/j.jag.2014.08.011.

Peng, Y, Zeng, A, Zhu, T, Fang, S, Gong, Y, Tao, Y, Zhou, Y \& Liu, K 2017, 'Using remotely sensed spectral reflectance to indicate leaf photosynthetic efficiency derived from active fluorescence measurements', Journal of Applied Remote Sensing, vol. 11(2), pp. 1-15, doi:10.1117/1.jrs.11.026034.

Peñuelas, J, Baret, F \& Filella, I 1995, 'Semi-empirical indices to assess carotenoids/chlorophyll-a ratio from leaf spectral reflectance', Photosynthetica, vol. 31, pp. 221-230.

Peñuelas, J \& Filella, I 1998, 'Visible and near-infrared reflectance techniques for diagnosing plant physiological status', Trends in Plant Science, vol. 4, no. 3, pp. 151-156.

Pilar CM 2013, Chlorophyll fluorescence response to water and nitrogen deficit. The University of Arizona, Arizona, USA, $\mathrm{PhD}$ thesis.

Plessis J 2003, Maize Production, Available from: Directorate Agricultural Information Services. [27.04.2020].

Rolph, G 1873, Something about sugar: its history, growth, manufacture and distribution, San Francisco, J. J. Newbegin.

Schreiber, U, Bilger, W \& Neubauer, C 1995, 'Chlorophyll fluorescence as a nonintrusive indicator for rapid assessment of in vivo photosynthesis', Springer Berlin Heidelberg.

Tan, CW, Huang, WJ, Jin, XL, Wang, JC, Tong, L, Wang, JH \& Guo, WS 2012, 'Monitoring the chlorophyll fluorescence parameter $\mathrm{Fv} / \mathrm{Fm}$ in compact corn based on different hyperspectral vegetation indices', Spectroscopy and Spectral Analysis, vol. 32(5), pp. 1287-1291.

Wei, J, Tang, X, Gu, Q, Wang, M, Ma, M, \& Han, X 2019, 'Using solar-induced chlorophyll fluorescence observed by OCO-2 to predict autumn crop production in China', Remote Sensing, vol. 11(14), 1715, pp. 1-14, doi:10.3390/ rs11141715.

Wilson, JH 1968 'Water relations of maize. Effects of severe soil moisture stress imposed at different stages of growth on grain yields of maize', Rhodesia agricultural journal, vol. 6 , pp. 103-105.

Zagajeski, B, Kycko, M, Tømmervik, H, Bochenek, Z, Wojtuń, B, Bjerke, J \& Kłos, A 2018, 'Feasibility of hyperspectral vegetation indices for the detection of chlorophyll concentration in three high Arctic plants: Salix polaris, Bistorta vivipara, and Dryas octopetala', Acta Societatis Botanicorum Poloniae, 87(4):3604, doi. 10.5586/asbp.3604.
Zagajewski, B, Tømmervik, H, Bjerke, J, Raczko, E, Bochenek, Z, Kłos, A, Jarocińska, A, Lavender, S \& Ziółkowski, D 2017, 'Intraspecific Differences in Spectral Reflectance Curves as Indicators of Reduced Vitality in High-Arctic Plants', Remote Sensing, vol. 9(12), 1289, doi:10.3390/rs9121289.

Zarco-Tejada, PJ, Morales, A, Testi, L, \& Villalobos, FJ 2013, 'Spatio-temporal patterns of chlorophyll fluorescence and physiological and structural indices acquired from hyperspectral imagery as compared with carbon fluxes measured with eddy covariance', Remote Sensing of Environment, 133, pp. 102-115. 